\title{
Analisis Pemanfaatan Hutan Mangrove Oleh Masyarakat Kampung Nipah Desa Sei Nagalawan Kecamatan Perbaungan Kabupaten Serdang Bedagai
}

\author{
Elfia Nurjana Ndruru' ${ }^{1}$, dan Fitra Delita ${ }^{2}$ \\ Program studi Pendidikan Geografi, Universitas Negeri Medan, Medan \\ e-mail: elfia.ndruru@gmail.com
}

\begin{abstract}
ABSTRAK. Tujuan Penelitian : 1) menganalisis ekosistem mangrove di Kampung Nipah Desa Sei Nagalawan, 2) menganalisis pengelolaan hutan mangrove di Kampung Nipah Desa Sei Nagalawan, dan 3) menganalisis pemanfaatan hutan mangrove di Kampung NipahDesa Sei Nagalawan Kabupaten Serdang Bedagai. Populasi sekaligus sampel dalam penelitian ini adalah kawasan hutan mangrove seluas 5 Ha di Kampung Nipah Desa Sei Nagalawan dengan $40 \mathrm{KK}$ informan sebagai data pedukung. Teknik pengumpulan data yang digunakan adalah teknik komunikasi langsung berupa wawancara, selain itu juga menggunakan obsevasi dan dokumentasi. Teknik analisis data yang dilakukan adalah deskriptif kualitatif. Hasil penelitian menunjukkan (1) ekosistem hutan mangrove di Kampung Nipah terdiri dari komponen biotik yaitu dari jenis vegetasi, jenis fauna dan zonasi mangrove. Komponen abiotik terdiri dari suhu, cahaya, air dan tanah. (2) masyarakat di Kampung Nipah mengelola hutan mangrove meliputi tahap perencanaan, pelaksanaan, evaluasi dan (3) masyarakat juga memanfaatkan hutan mangrove, baik manfaat langsung, manfaat tidak langsung maupun manfaat pilihan. Manfaat langsung masyarakat memanfaatkannya dengan cara mengolah mangrove dalam bentuk makanan, perikanan, maupun bahan industri rumah tangga seperti arang, kayu bakar, dan zat pewarna. Manfaat tidak langsung masyarakat mengetahui fungsi dari hutan mangrove tersebut, seperti mencari makan dan daerah pemijahan dari berbagai biota laut, tempat bersarangnya burung, habitat alami bagi berbagai jenis biota, melindungi pantai dari abrasi dan intrusi air laut, penghasil oksigen, mencegah gelombang air laut, dan melindungi pantai dari badai dan taufan. Sedangkan manfaat pilihan, masyarakat membuat tempat ekowisata di Pantai Mangrove Kampung Nipah.
\end{abstract}

Kata kunci: Ekosistem Mangrove, Pengelolaan dan Pemanfaatan Hutan Mangrove 


\section{PENDAHULUAN}

Indonesia merupakan salah satu negara yang mempunyai garis tepi laut terpanjang didunia. Panjang garis tepi laut Indonesia sekitar 81.000 kilometer. Indonesia juga mempunyai perairan yang luas 2/3 dari luas wilayah keseluruhan (Kementerian Kelautan dan Perikanan, 2019). Wilayah perairan membentuk zona pesisir dan zona lautan yang berperan penting dalam mendukung penghidupan penduduk. Kekayaan yang ada di wilayah pesisir Indonesia baik sumber daya hayati dan nonhayati. Kekayaan dan keunikan ini dapat dimanfaatkan untuk sektor pereknomian melalui kegiatan pertambangan, perikanan, kehutanan, industri, pariwisata serta inovasi kemampuan lainnya.

Wilayah pesisir menggambarkan suatu ekosistem transisi yang dipengaruhi oleh daratan serta lautan, mencakup sebagian ekosistem, salah satunya termasuk ekosistem hutan mangrove. Hutan mangrove menjelaskan bahwa ekosistem utama pendukung kehidupan berarti di daerah pesisir serta kelautan. Hutan mangrove mempunyai guna biologis selaku penyedia nutrien untuk biota perairan, tempat pemijahan serta asuhan (nursery ground) bermacam berbagai biota. Guna ekologis hutan mangrove selaku penahan abrasi pantai, amukan angin taufan serta tsunami, penyerap limbah, penyerap $\mathrm{CO} 2$ serta penghasil $\mathrm{O} 2$ yang relatif besar dibandingkan jenis hutan yang lain (Binawati, 2015).

Hutan mangrove pula memiliki guna ekonomis. Keindahan dan keunikan hutan mangrove menjadi daya tarik wisata diwilayah pesisir. Kedatangan pengunjung akan membuka kesempatan bagi masyarakat untuk menambah penghasilan. Ekosistem hutan mangrove yang menjadi habitat berbagai fauna, pemijahan ikan, udang serta biota lainnya dapat menjadi sumber pendapatan bagi masyarakat. Selain itu, kayu mangrove pula bisa dijadikan bahan bangunan, furniture serta bahan pembuatan kapal.

Indonesia memiliki hutan mangrove terluas didunia yaitu 3.489.140,68 Ha pada tahun 2015 (Humas Kementerian LHK, 2017). Hutan mangrove seluas 1.671.140,75 Ha dalam keadaan baik, sisanya hutan mangrove seluas 1.817.999,93 Ha dalam keadaan rusak. Keadaan hutan mangrove semakin menurun baik dari segi kualitas dan kuantitas. Hal ini dikarenakan pemanfaatan yang berlebihan dan tidak bertanggung jawab. Seharusnya untuk kelestarian mangrove perlu dilakukan pengelolaan secara seimbang misalnya dengan menanam kembali mangrove.

Begitu juga dengan kondisi hutan mangrove di Provinsi Sumatera Utara. Berdasarkan data Yayasan Gajah Sumatera dalam Tambunan (2018), pada tahun 1989 luas mangrove di Sumatera Utara sekitar $96.000 \mathrm{Ha}$, pada tahun 2002 berkurang menjadi $63.000 \mathrm{Ha}$, pada tahun 2009 menjadi 26.000 Ha. Penyusutan luas hutan mangrove tersebut menjadi keprihatinan bagi berbagai kalangan. Pencegahan bertambahnya kerusakan mangrove terus dilakukan dengan menanam mangrove kembali di kawasan pesisir. Penanaman mangrove ini melibatkan pemerintah, LSM, perguruan tinggi dan masyarakat sekitar. Pada tahun 2014 upaya ini sudah mulai berhasil dengan meningkatnya luas mangrove menjadi 36.000 Ha. Pada tahun 2020 luas hutan mangrove di Provinsi Sumatera Utara telah mencapai 65.000 Ha (Media Sumut, 2020). 
Ekosistem hutan mangrove tersebar diberbagai pesisir Provinsi Sumatera Utara. Salah satu ekosistem mangrove tersebut berada di Kampung Nipah. Kampung Nipah adalah kawasan wisata hutan mangrove yang berada di Desa Sei Nagalawan, Kabupaten Serdang Bedagai, Sumatera Utara. Luas hutan mangrove di Kampung Nipah ini sekitar 5 Ha (Tambunan, 2018). Berdasarkan studi pendahuluan diperoleh informasi bahwa masyarakat Kampung Nipah menjadikan hutan mangrove selaku tempat mata pencaharian. Masyarakat menggunakan bermacam kemampuan yang ada di hutan mangrove. Pemanfaatan tersebut salah satunya sebagai kawasan wisata. Kedatangan pengunjung akan membawa dampak pada perekonomian masyarakat. Pemanfaatan lainnya adalah sebagai lahan tambak. Selain itu pemanfaatan mangrove juga sebagai bahan bangunan, bahan makanan dan minuman. Pemanfaatan hutan mangrove secara berlebihan akan mengganggu kelestarian ekosistemnya. Pemanfaatan hutan mangrove tentunya perlu memperhatikan aspek ekologis. Hal ini dikarenakan fungsi ekologis mangrove sebagai penahan abrasi, pencegah intrusi air laut, penyerap $\mathrm{CO} 2$ dan menghasilkan oksigen.

\section{METODE PENELITIAN}

Penelitian ini dilakukan di pesisir Daerah Kampung Nipah Desa Sei Nagalawan Kecamatan Perbaungan Kabupaten Serdang Bedagai. Alasan pemilihan lokasi ini adalah hutan mangrove di Kampung Nipah sudah mengalami pemulihan setelah dahulunya pernah mengalami kerusakan. Kemudian mata pencaharian masyarakat sangat bergantung pada hutan mangrove. Penelitian dilaksanakan pada 8 Februari 2021 sampai 8 Maret 2021.

Populasi sekaligus sampel dalam penelitian ini adalah kawasan hutan mangrove seluas 5 Ha di Kampung Nipah Desa Sei Nagalawan, Kecamatan Perbaungan, Kabupaten Serdang Bedagai. Kawasan ini dijadikan sampel untuk menganalisis karakteristik hutan mangrove dan pemanfaatannya oleh masyarakat Pada kawasan ini sudah diberikan izin hutan kemasyarakatan oleh Dinas Kehutanan Provinsi Sumatera Utara seluas 2 Ha. Hutan kemasyarakatan telah memberikan manfaat bagi $40 \mathrm{KK}$ yang ada di Kampung Nipah ini. Informan dalam penelitian ini adalah ketua kelompok pengelola di Kampung Nipah Bapak Sutrisno dan masyarakat sebanyak $40 \mathrm{KK}$. Teknik pengumpulan data yang digunakan adalah teknik komunikasi langsung berupa wawancara, selain itu juga menggunakan obsevasi dan dokumentasi. Teknik analisis data yang dilakukan adalah deskriptif kualitatif.

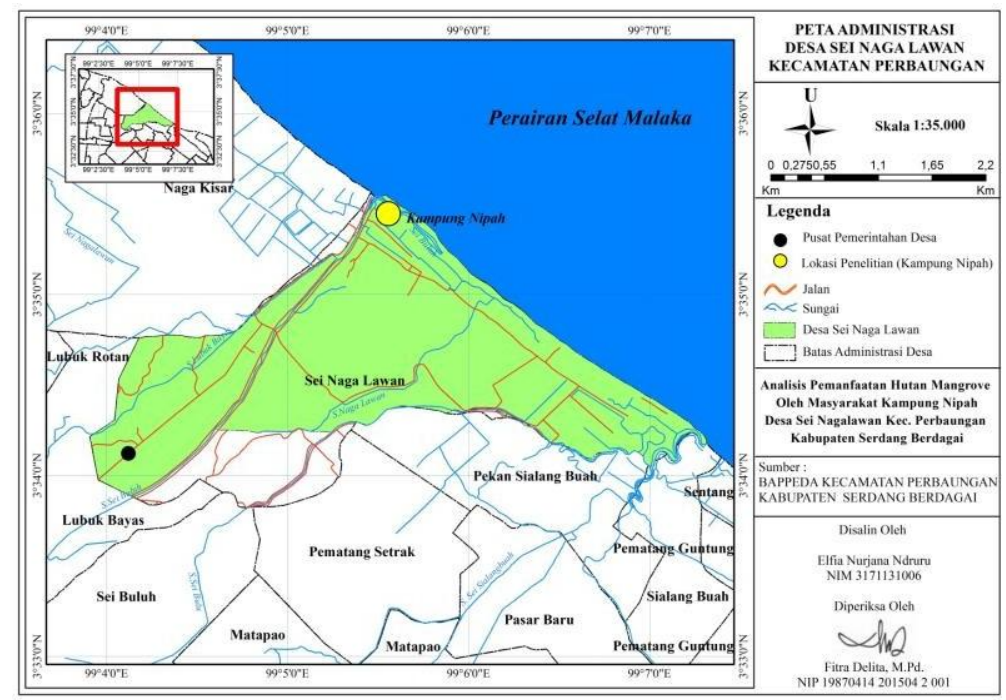

Gambar 1. Kampung Nipah Kabupaten Serdang Bedagai 


\section{HASIL DAN PEMBAHASAN}

\section{Hasil}

\section{Ekosistem Hutan Mangrove di Kampung Nipah Serdang Bedagai}

Ekosistem mangrove merupakan ekosistem peralihan antara darat dan laut yang dikenal memiliki peran dan fungsi yang sangat besar. Terdapat komponen biotik dan abiotik dalam ekosistem hutan mangrove di Kampung Nipah Serdang Bedagai. Pertama, komponen biotik yang dimana terdapat jenis-jenis vegetasi dan jenis fauna yang terdapat di Kampung Nipah. Jenis-jenis vegetasi yang ditemukan pada kawasan ekosistem hutan mangrove di Kampung Nipah terdiri dari dua kategori yaitu pertama mangrove sejati (true mangrove) merupakan jenis mangrove yang tumbuh di tempat pasang surut air laut dengan substrat berlumpur asin yang memiliki kadar salinitas tinggi mulai dari dekat dengan laut sampai ke daratan dan yang kedua mangrove asosiasi yang merupakan jenis tumbuhan yang mampu beradaptasi dengan salinitas atau dikenal mangrove pendamping. Kedua, komponen abiotik yang dimana terdapat suhu, cahaya, air, dan tanah. Komponen abiotik dapat mempengaruhi biotik, begitu pula dengan sebaliknya, sehingga hutan mangrove di Kampung Nipah dapat hidup sesuai dengan habitatnya.

Tabel 1.Jenis-jenis mangrove sejati dan mangrove asosiasi yang ditemukan di Kampung Nipah dengan berbagai karakteristiknya.

\begin{tabular}{|c|c|c|c|c|}
\hline No & Nama Lokal & Nama Ilmiah & Karakteristik & Keterangan \\
\hline (1) & $(2)$ & (3) & (4) & (5) \\
\hline 1 & Bakau Merah & $\begin{array}{l}\text { Rhizophora } \\
\text { apiculata }\end{array}$ & $\begin{array}{l}\text { Tinggi pohon mencapai } 15-30 \text { meter. } \\
\text { Kulit kayunya bercorak abu-abu gelap } \\
\text { dan terkadang coraknya mampu } \\
\text { berubah-ubah. Daunnya bercorak hijau } \\
\text { tua dengan hijau muda pada bagian } \\
\text { tengah dan kemerahan di bagian } \\
\text { bawah, berbentuk elips dan ujung } \\
\text { daunnya meruncing. }\end{array}$ & $\begin{array}{l}\text { Mangrove } \\
\text { Sejati }\end{array}$ \\
\hline 2 & Bakau Bangka & $\begin{array}{l}\text { Rhizhopora } \\
\text { Mucronata }\end{array}$ & $\begin{array}{l}\text { Jenis bakau bangka ini termasuk jenis } \\
\text { bakau pada umumnya. Tinggi pohon } \\
\text { mencapai } 15-27 \text { meter. Kulit kayunya } \\
\text { bercorak gelap hingga hitam serta } \\
\text { terdapat celah horizontal. Daunnya } \\
\text { berbentuk elips melebar dengan ujung } \\
\text { daunnya meruncing. Tangkai daun } \\
\text { berwarna hijau-kekuningan. }\end{array}$ & $\begin{array}{l}\text { Mangrove } \\
\text { Sejati }\end{array}$ \\
\hline 3 & $\begin{array}{l}\text { Bakau, } \\
\text { Tongke-Besar }\end{array}$ & $\begin{array}{l}\text { Rhizhopora } \\
\text { Stylosa }\end{array}$ & $\begin{array}{l}\text { Pohon yang tingginya menggapai } 10 \\
\text { meter. Kulit kayunya halus bercorak } \\
\text { abu-abu sampai hitam. Daunnya mirip } \\
\text { seperti bakau bangka berbentuk elips } \\
\text { melebar dan ujung daunnya } \\
\text { meruncing. Memiliki akar tunjang } \\
\text { dengan panjang hingga } 3 \text { meter. }\end{array}$ & $\begin{array}{c}\text { Mangrove } \\
\text { Sejati }\end{array}$ \\
\hline 4 & Api-api & Avicinnea Alba & $\begin{array}{l}\text { Tanaman ini tumbuh subur di daerah } \\
\text { depan (daerah yang sangat dekat } \\
\text { dengan laut). Bisa tumbuh hingga } 20 \\
\text { meter dan permukaan batangnya } \\
\text { halus. Daunnya bercorak hijau } \\
\text { mengkilat dan bawah daunnya pucat. }\end{array}$ & $\begin{array}{c}\text { Mangrove } \\
\text { Sejati }\end{array}$ \\
\hline 5 & Api-api Putih & $\begin{array}{l}\text { Avicinnea } \\
\text { Marina }\end{array}$ & $\begin{array}{l}\text { Tinggi pohon mencapai } 30 \text { meter. } \\
\text { Kulit kayu halus berwarna pucat sering } \\
\text { kali terkelupas kecil-kecil. Tumbuhan } \\
\text { ini pun yang paling umum dijumpai. } \\
\text { Daunnya berwujud elips hingga oval } \\
\text { dan bercorak hijau bawah daunnya }\end{array}$ & $\begin{array}{l}\text { Mangrove } \\
\text { Sejati }\end{array}$ \\
\hline
\end{tabular}




\begin{tabular}{|c|c|c|c|c|}
\hline & & & bercorak pucat. & \\
\hline 6 & Api-api & Avicinnea lanata & $\begin{array}{l}\text { Pohon tumbuhan nya tegak dan } \\
\text { menyebar, dapat mencapai ketinggian } 8 \\
\text { meter. Kulit kayunya berwarna gelap, } \\
\text { coklat hingga hitam. Daunnya } \\
\text { berbentuk elips ujungnya membundar } \\
\text { agak meruncing. }\end{array}$ & $\begin{array}{c}\text { Mangrove } \\
\text { Sejati }\end{array}$ \\
\hline 7 & Teruntum & $\begin{array}{l}\text { Lumnitzera } \\
\text { Racemosa }\end{array}$ & $\begin{array}{l}\text { Tanaman kecil yang selalu hijau dan } \\
\text { berkembang dengan ketinggian pohon } \\
\text { menggapai } 6 \text { meter. Akarnya menyebar } \\
\text { di tanah. Kulit luarberwarna abu-abu } \\
\text { hingga coklat kemerahan, dengan } \\
\text { retakan. Daunnya berwaarna hijau } \\
\text { mengkilat pada bagian atas sedangkan } \\
\text { bagian bawahnya pucat terkadang juga } \\
\text { bercampur warna agak kemerahan. } \\
\text { Bentuk daunnya bulat hingga elips } \\
\text { ujungnya membundar. }\end{array}$ & $\begin{array}{c}\text { Mangrove } \\
\text { Sejati }\end{array}$ \\
\hline 8 & Lenggadai & $\begin{array}{l}\text { Bruguiera } \\
\text { parviflora }\end{array}$ & $\begin{array}{l}\text { Pohonnya selalu hijau, ketinggian } \\
\text { pohonnya mencapai } 23 \text { meter. Kulit } \\
\text { kayu abu-abu, relatif halus. Bagian atas } \\
\text { daunnya berwarna hijau cerah } \\
\text { sedangkan bagian bawahnya hijau agak } \\
\text { kekuningan. Bentuknya elips agak } \\
\text { meruncing. }\end{array}$ & $\begin{array}{c}\text { Mangrove } \\
\text { Sejati }\end{array}$ \\
\hline 9 & Tengar & Ceriops tagal & $\begin{array}{l}\text { Pohonnya kecil dan bersemak dengan } \\
\text { ketinggian mencapai } 25 \text { meter. Kulit } \\
\text { kayu tengar bercorak abu-abu, } \\
\text { terkadang coklat, halus serta } \\
\text { pangkalnya menggelembung. Daunnya } \\
\text { hijau mengkilap dan memiliki } \\
\text { pinggiran daunnya yang menjulang ke } \\
\text { dalam. Bentuknya bulat telur terbalik- } \\
\text { elips dan ujungnya membundar. }\end{array}$ & $\begin{array}{c}\text { Mangrove } \\
\text { Sejati }\end{array}$ \\
\hline 10 & Mata Buaya & $\begin{array}{l}\text { Bruguiera } \\
\text { gymnorrhiza }\end{array}$ & $\begin{array}{l}\text { Mangrove tipe ini dapat tumbuh } \\
\text { mencapai } 15 \text { meter. Permukaan } \\
\text { batangnya bercorak hitam, dan halus. } \\
\text { Daunnya berbentuk elips berwarna } \\
\text { hijau. Tangkai daunnya seringkali } \\
\text { berwarna merah. }\end{array}$ & $\begin{array}{c}\text { Mangrove } \\
\text { Sejati }\end{array}$ \\
\hline 11 & Nipah & Nypa fruticans & $\begin{array}{l}\text { Tumbuhan yang menyerupai palem. } \\
\text { Tumbuhan ini bisa mencapai } \\
\text { ketinggian } 10 \text { meter. Panjang daunnya } \\
\text { bisa menggapai } 9 \text { meter. Setiap } \\
\text { tangkainya terdapat } 100 \text { hingga } 120 \\
\text { pinak. Buahnya tersusundalamtandan, } \\
\text { berbentuk bulat. }\end{array}$ & $\begin{array}{c}\text { Mangrove } \\
\text { Sejati }\end{array}$ \\
\hline 12 & Prepat & $\begin{array}{l}\text { Scyphiphora } \\
\text { hydrophyllacea }\end{array}$ & $\begin{array}{l}\text { Tumbuhan ini mencapai ketiggian } 3 \\
\text { meter, hijau selalu, seringkali memiliki } \\
\text { banyak cabang. Ujung pucuk berwarna } \\
\text { merah saat masih muda. Biasanya } \\
\text { tumbuh di atas substrat lumpur, pasir } \\
\text { dan karang di tepi lahan mangrove. } \\
\text { Daunnya berbentuk oval ataupun bulat } \\
\text { telur terbalik dengan ujung membulat. }\end{array}$ & $\begin{array}{c}\text { Mangrove } \\
\text { Sejati }\end{array}$ \\
\hline 13 & Jeruju & $\begin{array}{l}\text { Acanthus } \\
\text { ilicifolius }\end{array}$ & $\begin{array}{l}\text { Tanaman berbentuk herba agak } \\
\text { berkayu dengan besar menggapai } 2 \\
\text { meter. Tipe ini umumnya berkembang } \\
\text { di bagian belakang mangrove. Tepi } \\
\text { daun bergerigi atau agak rata, dan }\end{array}$ & $\begin{array}{c}\text { Mangrove } \\
\text { Sejati }\end{array}$ \\
\hline
\end{tabular}




\begin{tabular}{|c|c|c|c|c|}
\hline & & & $\begin{array}{l}\text { lambat laun menyempit ke pangkalnya. } \\
\text { Buahnya hampir menyerupai } \\
\text { belimbing, saat muda berwarna hijau } \\
\text { mengkilat, panjang } 2,5-3 \mathrm{~cm} \text {. }\end{array}$ & \\
\hline 14 & $\begin{array}{l}\text { Kacang- } \\
\text { kacangan }\end{array}$ & $\begin{array}{l}\text { Ipomoea pes- } \\
\text { caprae }\end{array}$ & $\begin{array}{l}\text { Termasuk herba abadi dengan batang } \\
\text { antara 5-30 meter. Buah bercorak hijau } \\
\text { bulat dengan empat biji bermotif gelap. } \\
\text { Daun tunggal, tebal serta bercorak } \\
\text { hijau mengkilat. Wujud daun semacam } \\
\text { tapak kuda. }\end{array}$ & $\begin{array}{l}\text { Mangrove } \\
\text { Asosiasi }\end{array}$ \\
\hline 15 & $\begin{array}{l}\text { Subang- } \\
\text { subang }\end{array}$ & Scaevola taccada & $\begin{array}{l}\text { Pohon yang dapat tumbuh mencapai } \\
\text { ketinggian hingga } 3 \text { meter. Bentuk } \\
\text { daunnya bulat telur terbalik hingga } \\
\text { elips. Daun menjalar ke atas, berwarna } \\
\text { kuning kehijauan dan mengkilat, } \\
\text { ujungnya melengkung, dan permukaan } \\
\text { daunnya seperti lapisan lilin. }\end{array}$ & $\begin{array}{l}\text { Mangrove } \\
\text { Asosiasi }\end{array}$ \\
\hline 16 & Gelang Laut & $\begin{array}{l}\text { Sesuvium } \\
\text { portuculacastrum }\end{array}$ & $\begin{array}{l}\text { Tanaman yang tercantum herba } \\
\text { tahunan, menjalar serta mempunyai } \\
\text { cabang. Panjang batang menggapai } 1 \\
\text { meter. Batang berdaging, bercorak } \\
\text { kemerahan serta berkembang pangkal } \\
\text { pada ruas-ruasnya. Buah semacam } \\
\text { kapsul, bundar serta halus, panjang } \\
\text { kurang lebih } 8 \text { milimeter. Umumnya } \\
\text { ditemukan di zona belakang mangrove } \\
\text { serta pertambakan; gosong pasir } \\
\text { ataupun tepi tepi laut yang tidak sering } \\
\text { tergenang dikala pasang. Bunga } \\
\text { berdimensi kecil, bercorak ungu } \\
\text { keputih-putihan. }\end{array}$ & $\begin{array}{l}\text { Mangrove } \\
\text { Asosiasi }\end{array}$ \\
\hline 17 & Ketapang & $\begin{array}{l}\text { Terminalia } \\
\text { catappa }\end{array}$ & $\begin{array}{l}\text { Tumbuhan dengan ketinggian } 10-35 \\
\text { meter, percabangan selalu mendatar. } \\
\text { Daun lebar berupa oval, bercorak hijau } \\
\text { mengkilap, dikala tua bercorak merah. } \\
\text { Bunga bercorak putih atau hijau pucat } \\
\text { serta tidak bergagang. }\end{array}$ & $\begin{array}{l}\text { Mangrove } \\
\text { Asosiasi }\end{array}$ \\
\hline 18 & Pidada & Sonneratia alba & $\begin{array}{l}\text { Pohon tinggi mencapai } 20 \text { meter. } \\
\text { Menggemari tanah yang bercampur } \\
\text { lumpur serta pasir, kadang-kadang } \\
\text { pada batuan serta karang. Selalu } \\
\text { ditemui di posisi pesisir yang } \\
\text { terlindung dari hempasan gelombang, } \\
\text { tipe ini selalu ditemukan di bagian } \\
\text { terdepan mangrove. Duduk daun } \\
\text { berhadapan dengan permukaan daun } \\
\text { bercorak hijau pucat berbentuk bulat } \\
\text { telur, ujung membulat. }\end{array}$ & $\begin{array}{l}\text { Mangrove } \\
\text { Sejati }\end{array}$ \\
\hline 19 & Waru & $\begin{array}{l}\text { Hibiscus } \\
\text { Tillaceus }\end{array}$ & $\begin{array}{l}\text { tumbuhan dengan tinggi } 2-10 \text { meter. } \\
\text { Tumbuh dengan baik di daerah pesisir } \\
\text { dan daerah belakang hutan bakau; } \\
\text { kadang ditemukan tumbuh di daerah } \\
\text { pasang surut. Daunnya berbentuk hati, } \\
\text { agak lebih tebal, dan permukaannya } \\
\text { licin dengan pola hijau mengkilat. } \\
\text { Bunga berbentuk lonceng berwarna } \\
\text { kuning muda saat mekar (sore hari), } \\
\text { dan bagian tengah bawah berwarna } \\
\text { jingga /hitam, kemudian seluruh bunga } \\
\text { berubah warna menjadi jingga dan } \\
\text { jatuh keesokan harinya. }\end{array}$ & $\begin{array}{c}\text { Mangrove } \\
\text { Asosiasi }\end{array}$ \\
\hline
\end{tabular}




\begin{tabular}{|c|c|c|c|c|}
\hline 20 & Cemara Laut & $\begin{array}{l}\text { Casuarina } \\
\text { Equisetipolia }\end{array}$ & $\begin{array}{l}\text { Tumbuhan berupa tumbuhan besar } \\
\text { dengan tinggitidak lebih dari } 30 \text { meter; } \\
\text { kulit kayunya agak pecah-pecah dan } \\
\text { ditandai dengan warna abu-abu } \\
\text { kecoklatan. Di daerah pantai berpasir, } \\
\text { asosiasi bakau yang lebih umum telah } \\
\text { muncul. Selalu ditanam di taman } \\
\text { sebagai tanaman peneduh dan elemen } \\
\text { dekoratif. Daunnya berbentuk jarum, } \\
\text { bergerombol di ujung cabang (biasanya } \\
7-8 \text { helai). }\end{array}$ & $\begin{array}{c}\text { Mangrove } \\
\text { Asosiasi }\end{array}$ \\
\hline 21 & Buta-buta & $\begin{array}{l}\text { Excoecaria } \\
\text { agallocha }\end{array}$ & $\begin{array}{l}\text { Tumbuhan dengan batang bercorak } \\
\text { abu-abu halus tetapi berbintil. Tinggi } \\
\text { pohon butan-buta menggapai } 15 \\
\text { meter. Batang, dahan serta daun } \\
\text { bergetah putih lengket. Tanaman ini } \\
\text { membutuhkan pasukan air yang } \\
\text { lumayan besar yaitu air tawar. Sangat } \\
\text { universal ditemukan di bagian belakang } \\
\text { hutan mangrove yang berkadar } \\
\text { salinitas rendah. Daun elips dengan } \\
\text { ujung meruncing, bercorak hijau, } \\
\text { dikala tua hendak berganti menjadi } \\
\text { merah saat sebelum rontok. }\end{array}$ & $\begin{array}{l}\text { Mangrove } \\
\text { Sejati }\end{array}$ \\
\hline 22 & $\begin{array}{l}\text { Ketapang Laut } \\
\text { (Nyamplung) }\end{array}$ & $\begin{array}{l}\text { Calophyllum } \\
\text { Inophyllum }\end{array}$ & $\begin{array}{l}\text { Tumbuhan bercorak hitam dan } \\
\text { berdaun lebat, tinggi menggapai } 30 \\
\text { meter, bergetah lengket bercorak } \\
\text { kuning atau putih. Berkembang di } \\
\text { zona berpasir dan tidak sering } \\
\text { ditemukan di hutan mangrove. Tipe } \\
\text { mangrove asosiasi biasanya dijadikan } \\
\text { sebagai tumbuhan peneduh atau } \\
\text { penghias. Bentuk elips atau agak } \\
\text { membulat, dan ujung tumpul. Bagian } \\
\text { atas daun bercorak hijau hitam, bagian } \\
\text { bawah hijau kekuningan. }\end{array}$ & $\begin{array}{c}\text { Mangrove } \\
\text { Asosiasi }\end{array}$ \\
\hline 23 & $\begin{array}{l}\text { Sukun/Tanjan } \\
\mathrm{g}\end{array}$ & $\begin{array}{l}\text { Bruguiera } \\
\text { Sexangula }\end{array}$ & $\begin{array}{l}\text { Pohonnya yang senantiasa hijau } \\
\text { dengan ketinggian menggapai } 30 \\
\text { meter. Permukaan kulit kayunya halus } \\
\text { sampai kasar, bercorak abu-abu tua } \\
\text { hingga coklat (warna berubah-ubah). } \\
\text { Daun agak tebal, berkulit, serta } \\
\text { mempunyai bercak hitam di bagian } \\
\text { dasar. }\end{array}$ & $\begin{array}{c}\text { Mangrove } \\
\text { Sejati }\end{array}$ \\
\hline 24 & Kedabu & Sonneratia Ovata & $\begin{array}{l}\text { Tumbuhan berdimensi kecil atau } \\
\text { sedang, umumnya ketinggiannya } \\
\text { sampai } 5 \text { meter, kadang-kadang } \\
\text { menggapai } 20 \text { meter. Daunnya panjang } \\
\text { menggapai } 2-15 \text { mm. Ujung daunnya } \\
\text { membundar dan bentuk daunnya bulat } \\
\text { telur. }\end{array}$ & $\begin{array}{c}\text { Mangrove } \\
\text { Sejati }\end{array}$ \\
\hline
\end{tabular}

Pada tabel 1 dijelaskan bahwa jenis mangrove sejati yang ditemukan di Kampung Nipah terdiri dari 17 jenis sedangkan mangrove asosiasi ditemukan 7 jenis dengan berbagai karakteristik yang berbeda-beda. Mulai dari jenis bakau merah, bakau bangka, tongke besar, api-api, api-api putih, teruntum, lenggadai, tengar, mata buaya, nipah, prepat, jeruju, kacang-kacangan, subangsubang, gelang laut, ketapang, pidada, waru, cemara laut, buta-buta, ketapang laut, sukun/tanjang, dan kedabu. 


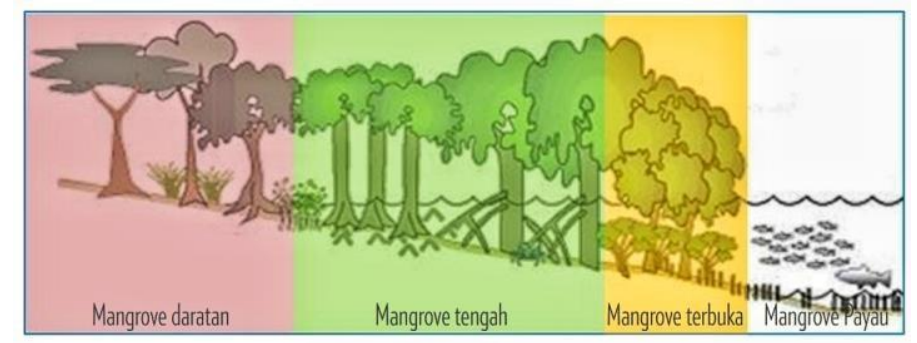

Gambar 2.Zonasi Mangrove Asia-Pasifik

Pada umumnya habitat vegetasi mangrove biasanya membentuk zonasi. Kampung Nipah, pola zonasi mangrove tidak jauh berbeda dengan mangrove di Asia, yaitu Avicennia spp serta Sonneratia spp, dibelakangnya berturut-turut merupakan zona Rhizophora spp, Bruguiera spp, Lumnitzera, Xylocarpus, Nypa serta berbagai mangrove asosiasilainnya.

Tabel 2. Zonasi Mangrove di Kampung Nipah

\begin{tabular}{|c|c|c|c|c|c|}
\hline \multirow[b]{2}{*}{ No } & \multirow[b]{2}{*}{ Nama Ilmiah Mangrove } & \multicolumn{4}{|c|}{ Zonasi Mangrove } \\
\hline & & $\begin{array}{c}\text { Mangrove } \\
\text { Terbuka }\end{array}$ & $\begin{array}{c}\text { Mangrove } \\
\text { Tengah }\end{array}$ & $\begin{array}{c}\text { Mangrove } \\
\text { Daratan }\end{array}$ & $\begin{array}{c}\text { Mangrove } \\
\text { Payau }\end{array}$ \\
\hline \multirow[t]{7}{*}{1.} & Avicinnea Alba & $\sqrt{ }$ & & & \\
\hline & Avicinnea Marina & $\sqrt{ }$ & & & \\
\hline & Avicinnea Lanata & $\sqrt{ }$ & & & \\
\hline & Sonneratia Alba & $\sqrt{ }$ & $\sqrt{ }$ & & \\
\hline & Sonneratia Ovata & $\sqrt{ }$ & & & \\
\hline & Scyphiphora Hydrophyllacea & $\sqrt{ }$ & & & \\
\hline & Ceriops Tagal & $\sqrt{ }$ & $\sqrt{ }$ & & \\
\hline \multirow[t]{11}{*}{2.} & Rhizophora Apiculata & $\sqrt{ }$ & $\sqrt{ }$ & & \\
\hline & Rhizophora Mucronata & & $\sqrt{ }$ & & \\
\hline & Rhizophora Stylosa & & $\sqrt{ }$ & & \\
\hline & Bruguiera Parviflora & & $\sqrt{ }$ & & \\
\hline & Bruguiera Gymnorrhiza & & $\sqrt{ }$ & & \\
\hline & Bruguiera Sexangula & & $\sqrt{ }$ & & \\
\hline & Ipomea Pes-Caprae & & $\sqrt{ }$ & $\sqrt{ }$ & \\
\hline & Scaevola Taccada & & $\sqrt{ }$ & $\sqrt{ }$ & \\
\hline & Sesuvium Portuculacastrum & & $\sqrt{ }$ & $\sqrt{ }$ & \\
\hline & Excoecaria Agallocha & $\sqrt{ }$ & $\sqrt{ }$ & & \\
\hline & Acanthus Ilicifolius & & $\sqrt{ }$ & $\sqrt{ }$ & $\sqrt{ }$ \\
\hline \multirow[t]{3}{*}{3.} & Hibiscus Tillaceus & $\sqrt{ }$ & $\sqrt{ }$ & & \\
\hline & Lumnitzera Racemosa & & $\sqrt{ }$ & $\sqrt{ }$ & \\
\hline & Terminalia Catappa & & & $\sqrt{ }$ & \\
\hline \multirow[t]{3}{*}{4.} & Nypa Fruticans & & & $\sqrt{ }$ & \\
\hline & Casuarina Equisetipolia & & & $\sqrt{ }$ & \\
\hline & Calophyllum Inophylum & & & $\sqrt{ }$ & \\
\hline
\end{tabular}

Pada tabel 2 menunjukkan bahwa jenis-jenis mangrove yang ada di Kampung Nipah berzonasi bergantung oleh kondisi tanah, salinitas, pasang surut, penggenangann, laju pengendapan, serta pengikisan. 
Tabel 3. Jenis fauna yang berada di Kampung Nipah Desa Sei Nagalawan

\begin{tabular}{|l|l|l|}
\hline No. & \multicolumn{1}{|c|}{ Jenis Fauna } & \multicolumn{1}{c|}{ Keterangan } \\
\hline 1. & Kepiting Bakau & $\begin{array}{l}\text { Kepiting ini hidup di ekosistem hutan mangrove, } \\
\text { kepiting ini juga termasuk salah satu komoditas } \\
\text { penting dalam perikanan. }\end{array}$ \\
\hline 2. & Ikan Lundu & $\begin{array}{l}\text { Ikan ini merupakan ikan lokal yang sering } \\
\text { ditemukan di perairan. Habitat aslinya di sungai } \\
\text { maupun di rawa-rawa. }\end{array}$ \\
\hline 3. & Udang Galah & $\begin{array}{l}\text { Udang yang memiliki ciri-ciri fisik lebih besar } \\
\text { daripada udang jenis lainnya. Udang ini hidup di } \\
\text { daerah perairan air tawar. }\end{array}$ \\
\hline 4. & Ikan Belanak & $\begin{array}{l}\text { Ikan belanak ini menyerupai ikan bandeng, bisa } \\
\text { dijumpai di air payau terkadang di air tawar juga } \\
\text { bisa. }\end{array}$ \\
\hline 5. & Bangau Putih & $\begin{array}{l}\text { Burung yang memiliki warna yang putih, biasanya } \\
\text { dijumpai di area yang kering, kebetulan sawah } \\
\text { yang ada di Kampung Nipah Desa Sei Nagalawan } \\
\text { ini memiliki sawah yang kering, sehingga bangau } \\
\text { putih menempati daerah tersebut. }\end{array}$ \\
\hline 6. & Ikan Tembakul & $\begin{array}{l}\text { Hewan yang habitatnya senang melompat-lompat } \\
\text { ke daratan, terutama di area berlumpur atau berair } \\
\text { dangkal di sekitar hutan bakau waktu air surut. }\end{array}$ \\
\hline 7. & Kelomang & $\begin{array}{l}\text { Kelomang ini tersembunyi di dalam cangkang } \\
\text { siput laut yang telah kosong. }\end{array}$ \\
\hline
\end{tabular}

Pada saat observasi yang dilakukan, adapun fauna yang berhabitat di hutan mangrove Kampung Nipah Desa Sei Nagalawan tersebut yaitu seperti kepiting bakau, ikan lundu, udang galah, ikan belanak, bangau putih, ikan tembakul, kelomang, dan beserta hewan lainnya yang tidak bisa saya teliti lebih dalam.

\section{Pengelolaan Hutan Mangrove Berbasis Masyarakat}

Pengelolaan hutan mangrove dalam penelitian ini adalah masyarakat dan beberapa kelompok LSM/Pemerintah dalam mengkonservasi dan rehabilitasi dalam rangka pemulihan serta optimalisasi fungsi dan manfaatnya yang sudah terjadi pada tahun 1980 dalam hal pertambakkan udang yang hampir diseluruh kawasan pesisir timur Sumatera Utara. Informan responden yang melakukan pengelolaan mangrove di Kampung Nipah merupakan kegiatan yang berdampak sangat penting bagi keberhasilan dan peningkatan fungsi lingkungan hutan mangrove di wilayah pesisir. Kegiatan pengelolaan mangrove meliputi tahap perencanaan, pelaksanaan dan evaluasi. Berdasarkan analisis data dapat diketahui bahwa jumlah dan tingkat partisipasi masyarakat dalam kegiatan pengelolaan mangrove menggambarkan skala partisipasi masyarakat dalam pengolahan mangrove.

Berdasarkan hasil wawancara dan survey lapangan yang sudah dilakukan di Kampung Nipah Desa Sei Nagalawan Kabupaten Serdang Bedagai dapat diambil suatu hasil yaitu sebagai berikut:

1) Tingkat partisipasi masyarakat pada tahap perencanaan

Berdasarkan hasil wawancara yang sudah dilakukan terhadap 40 KK di Kampung Nipah yang dijadikan sebagai informan secara keseluruhan, tingkat partisipasi masyarakat pada tahap perencanaan ini diukur dari frekuensi pertemuan sebelum keikutsertaan masyarakat dalam kegiatan penanaman mangrove, memanfaatkan mangrove dan antusiasme masyarakat dalam memberikan ide atau pendapat untuk meningkatkan kegiatan mangrove di Kampung Nipah. Berikut pada tabel 4. disajikan lebih rinci. 
Tabel 4. Distribusi masyarakat pada tahap perencanaan

\begin{tabular}{|c|c|c|c|}
\hline No. & Kategori & Jumlah Responden & Persentasi (\%) \\
\hline 1. & Tinggi & 33 & 82,50 \\
\hline 2. & Rendah & 7 & 17,50 \\
\hline & Total & 40 & 100,00 \\
\hline
\end{tabular}

Berdasarkan pada tabel 4 diketahui bahwa tingkat partisipasi masyarakat pada tahap perencanaan pengelolaan hutan mangrove yang tergolong dalam kategori tinggi sebesar 33 orang yaitu dengan proporsi $82,50 \%$, untuk kategori rendah sebesar 7 orang dengan proporsi $17,5 \%$. Masyarakat dalam kategori rendah merupakan masyarakat yang tidak pernah mengikuti atau hadir setiap kali diadakan pertemuan untuk merencanakan kegiatan dalam pengelolaan mangrove yang ada di Kampung Nipah. Masyarakat dalam kategori tinggi merupakan masyarakat yang sering mengikuti pertemuan dalam rangka perencanaan pengelolaan mangrove.

2) Tingkat partisipasi masyarakat pada tahap pelaksanaan

Pada tahap pelaksanaan, partisipasi masyarakat dilihat dari frekuensi partisipasi masyarakat dalam kegiatan penanaman mangrove yang diawali oleh individu, kelompok dan LSM/Pemerintah. Tingkat partisipasi pada tahap ini dapat disajikan pada Tabel 5.

Tabel 5. Distribusi masyarakat pada tahap pelaksanaan

\begin{tabular}{|c|c|c|c|}
\hline No. & Kategori & Jumlah Responden & Persentasi (\%) \\
\hline $\mathbf{1 .}$ & Tinggi & 29 & 72,50 \\
\hline $\mathbf{2 .}$ & Rendah & 11 & 27,50 \\
\hline & Total & $\mathbf{4 0}$ & $\mathbf{1 0 0 , 0 0}$ \\
\hline
\end{tabular}

Berdasarkan pada tabel 5 dapat diketahui bahwa tingkat partisipasi masyarakat pada tahap pelaksanaan yang tergolong tinggi sebesar 29 orang dengan proporsi 72,50\%, untuk kategori rendah sebesar 11 proporsinya $27,50 \%$. Masyarakat dalam kategori rendah merupakan masyarakat yang tidak pernah melakukan ataupun mengikuti kegiatan penanaman mangrove di Kampung Nipah dan masyarakat dengan kategori tinggi adalah masyakarat yang sering mengikuti kegiatan penanaman mangrove setiap kali diadakan kegiatan tersebut. Kampung Nipah Desa Sei Nagalawan selalu menyediakan bibit mangrove untuk kegiatan penanaman yang berlangsung untuk masyarakat pengelola ataupun dari berbagai pihak, mulai dari 100-500 bibit yang telah disediakan.

3) Tingkat partisipasi masyarakat pada tahap evaluasi

Partisipasi masyarakat pada tahap evaluasi dilihat dari kegiatan rapat pemeliharaan/menjaga kelestarian mangrove, supervisi dan evaluasi yang diadakan. Tingkat partisipasi masyarakat pada tahap ini disajikan pada Tabel 6.

Tabel 6. Distribusi masyarakat pada tahap evaluasi

\begin{tabular}{|l|c|c|c|}
\hline No. & Kategori & Jumlah Responden & Persentasi (\%) \\
\hline 1. & Tinggi & 35 & 87,50 \\
\hline 2. & Rendah & 5 & 12,50 \\
\hline & Total & $\mathbf{4 0}$ & $\mathbf{1 0 0 , 0 0}$ \\
\hline
\end{tabular}

Berdasarkan tabel 6 dapat diketahui bahwa tingkat partisipasi masyarakat dalam kategori tinggi sebesar 35 orang dengan proporsi 87,50\%, untuk kategori rendah sebesar 5 orang proporsinya $12,50 \%$. Masyarakat dalam kategori rendah adalah masyarakat yang tidak pernah mengikuti kegiatan pemeliharaan, pengawasan dan evaluasi saat dilakukan kegiatan tersebut. Masyarakat yang termasuk dalam kategori tinggi merupakan masyarakat yang sering dan aktif mengikuti kegiatan tersebut. 


\section{Pemanfaatan Hutan Mangrove}

Dalam penelitian ini pemanfaatan mangrove dibagi tiga, dari manfaat langsung, manfaat tidak langsung dan manfaat pilihan. Berdasarkan hasil wawancara yang dilakukan pada $40 \mathrm{KK}$ dapat diambil suatu hasil yaitu sebagai berikut:

1) Manfaat Langsung

Manfaat langsung yang diterima masyarakat di Kampung Nipah Desa Sei Nagalawan dari segi ekonomi berupa perikanan, hasil kayu, bagian buah mangrove yang diolah menjadi dodol dan beberapa makanan, dan lain-lain. Diuraikan dengan point-point sebagai berikut :

a. Perikanan

Perikanan merupakan suatu aktivitas yang berhubungan dengan pengelolaan serta pemanfaatan sumber energi ikan serta lingkungannya, mulai dari penciptaan, pengolahan hingga dengan pemasaran yang dilakukan. Hutan mangrove di Kampung Nipah berperan dalam meningkatkan perikanan skala kecil dan komersial. Perakaran mangrove menyediakan tempat untuk kehidupan biota-biota laut. Beberapa masyarakat di Kampung Nipah yang memanfaatkan perikanan dapat dilihat pada Tabel 7 berikut.

Tabel 7. Masyarakat Memanfaatkan Perikanan

\begin{tabular}{|c|c|c|c|}
\hline No. & Kategori & Jumlah Responden & Persentasi (\%) \\
\hline 1. & Tinggi & 10 & 25,00 \\
\hline 2. & Sedang & 5 & 12,00 \\
\hline 3. & Rendah & 25 & 63,00 \\
\hline \multicolumn{2}{|r|}{ Total } & 40 & 100,00 \\
\hline
\end{tabular}

Berdasarkan pada tabel 7 diketahui bahwa masyarakat dalam memanfaatkan hutan mangrove sebagai perikanan yang tergolong dalam kategori tinggi sebesar 10 orang yaitu dengan proporsi $25 \%$, untuk kategori sedang sebesar 5 orang yaitu dengan proporsi $12 \%$ dan kategori rendah sebesar 25 orang dengan proporsi 63\%. Masyarakat dalam kategori rendah merupakan masyarakat yang tidak sama sekali memanfaatkan hutan mangrove sebagai perikanan. Sedangkan kategori tinggi masyarakat memanfaatkan hutan mangrove sebagai perikanan, contoh nelayan dan jual beli-ikan bisa dilihat di Gambar 9.

b. Hasil Kayu

Pada dasarnya, batang pohon mangrove di Kampung Nipah dimanfaatkan sebagai bahan bakar, baik selaku kayu bakar ataupun diolah jadi arang untuk kebutuhan rumah tangga ataupun industri kecil. Tidak hanya itu, batang tumbuhan mangrove dapat dijadikan bahan bangunan ataupun penguat tanah. Bisa dilihat pada Gambar 10. Batang pohon mangrove diolah menjadi arang.

c. Dan lain-lain

Dalam hal ini "dan lain-lain" mangrove dapat dimanfaatkan sebagai bahan makanan maupun minuman. Pada gambar 3 dijelaskan bahwa contoh buah dan daun yang digunakan untuk diolah menjadi beberapa makanan dilakukan pada kelompok ibu-ibu pengelola di Kampung Nipah. Bagian daun diolah menjadi kerupuk sedangkan buah pidada diolah menjadi sirup. Bukan hanya itu saja, mangrove bisa diolah menjadi apapun jika mempunyai keterampilan. Hasil bisa dilihat di gambar 3. Akan tetapi keterbatasan buah sangat bergantung pada kondisi mangrove tiap tahunnya. 


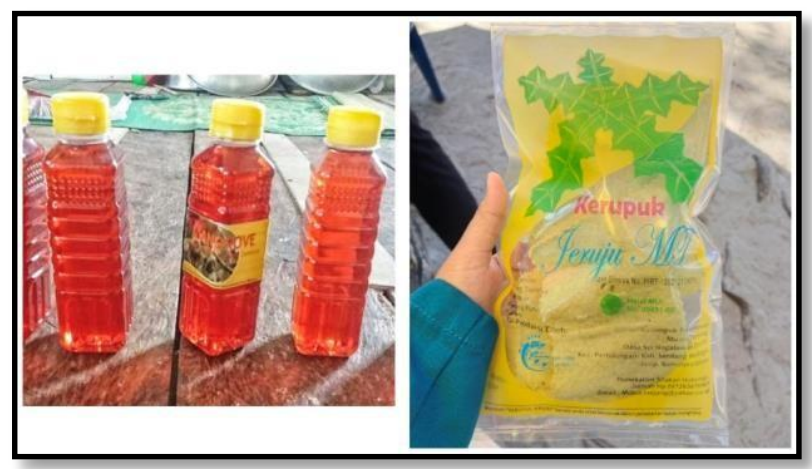

\section{Gambar 3. Hasil bagian mangrove daun dan buah yang diolah}

\section{2). Manfaat Tidak Langsung}

Manfaat tidak langsung yang diterima masyarakat $40 \mathrm{KK}$ berupa penahan abrasi dan gelombang air laut, penahan intrusi pantai, dan lain-lain. Diuraikan pada point-point sebagai berikut.

a. Penahan Abrasi dan Gelombang Air Laut

Abrasi pantai merupakan suatu pengikisan tanah pada pesisir pantai yang diakibatkan oleh gelombang air laut dan arus laut. Masyarakat di Kampung Nipah mengetahui manfaat hutan mangrove sebagai penahan abrasi dan gelombang air laut. Sehingga masyarakat yang berada di Kampung Nipah ikut melestarikan keberadaan mangrove. Dapat dilihat pada gambar 13. Situasi Abrasi Pantai yang terjadi di Pantai Mangrove dikarenakan kurangnya lahan untuk kegiatan penanaman mangrove di Kampung Nipah, sehingga terjadi abrasi pantai yang tidak terduga.

b. Penahan Intrusi Laut

Pemanfaatan mangrove secara tidak langsung, masyarakat $40 \mathrm{KK}$ dapat mengetahui hutan mangrove yang berada di Kampung Nipah sebagai penahan intrusi air laut, dikarenakan perakaran mangrove dapat mengendapkan lumpur yang telah tercampur dengan air asin, dengan hal ini hutan mangrove berperan penting untuk mengurangi intensitas air laut yang menyebar sampai ke daratan.

c. Dan lain-lain

Manfaat tidak langsung yang didapatkan oleh masyarakat Kampung Nipah selain penahan abrasi pantai dan penahan intrusi air laut yaitu melindungi pantai dari badai dan taufan dan penyedia bahan makanan serta pemijahan bagi biota-biota yang hidup di dalamnya. Dalam hal ini masyarakat mengetahui fungsi fisik dari keberadaan hutan mangrove.

\section{3) Manfaat Pilihan}

Manfaat pilihan yang diterima masyarakat di Kampung Nipah berupa tempat ekowisata di Pantai Mangrove, dengan bertujuan memiliki faktor pembelajaran buat menggantikan perilaku serta sikap seseorang jadi mempunyai kepedulian, tanggung jawab serta komitmen pelestarian terhadap area serta budaya. Ekowisata di Pantai Mangrove bisa dilihat Gambar 4 dibawah ini. 


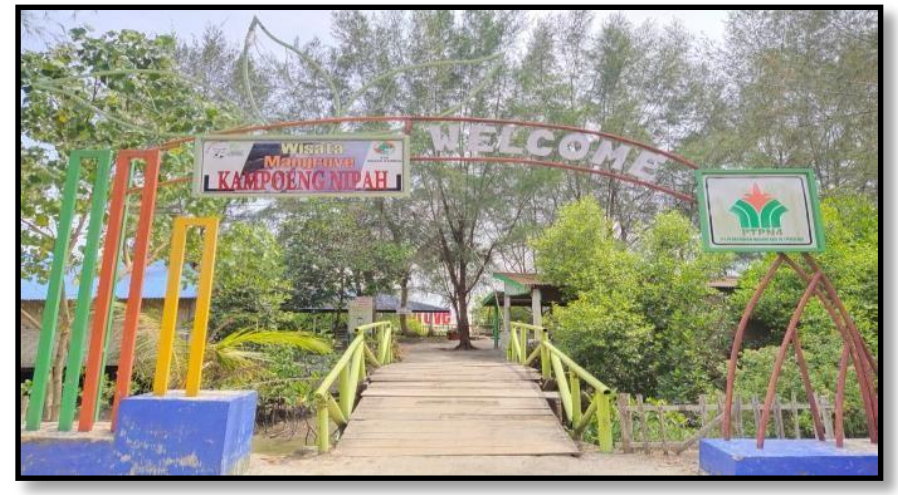

Gambar 4. Ekowisata di Pantai Mangrove

Pada gambar 5 menunjukkan adanya plang edukasi di Kampung Nipah yang diberikan oleh pihak Bank Sumatera Utara agar masyarakat, mahasiswa dan dosen dapat mempelajari manfaat apa saja yang terdapat di hutan mangrove, sehingga masyarakat bertambah pengetahuan dan ikut menjaga melestarikan hutan mangrove yang ada di Kampung Nipah Desa Sei Nagalawan.

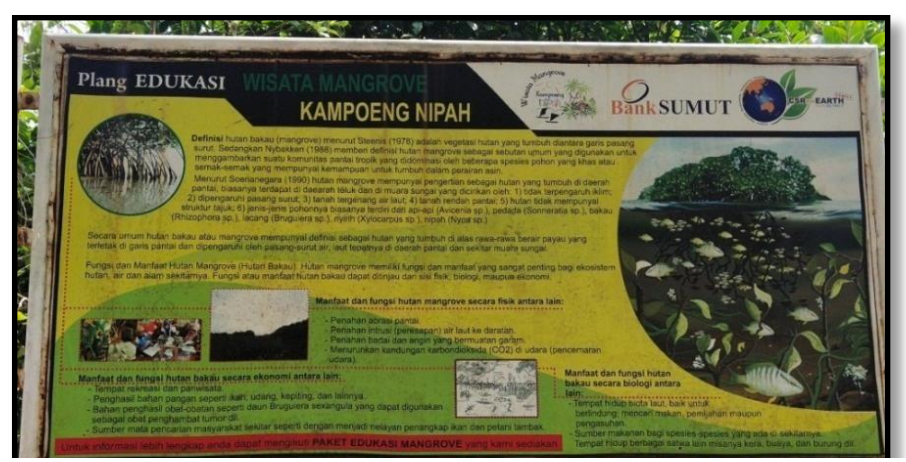

Gambar 5. Plang Edukasi tentang Mangrove

\section{Pembahasan}

\section{Ekosistem Hutan Mangrove}

Mangrove ialah suatu tanaman yang hidup di pasang surut air laut, tergenang waktu air pasang leluasa genangan waktu air surut. Hutan mangrove mempunyai ciri yang khas tersendiri, mengingat hidupnya terletak di daerah ekotone yaitu perairan dan daratan. Hal ini didukung oleh Kustanti (2011) dalam bukunya yang berjudul "Manajemen Hutan Mangrove" menjelaskan bahwa karakteristik dari hutan mangrove selain habitatnya yang unik, yaitu : mempunyai tipe pohon yang relatief sedikit. Mempunyai akar yang tidak beraturan (pneumatofora). Ekosistem mangrove memiliki peran baik secara ekologi, sosial-ekonomi dan sosial-budaya yang benar-benar mendukung untuk pemenuhan kebutuhan hidup manusia yaitu : sebagai pelindung serta penahan abrasi pantai, sebagai habitat fauna yang ada di hutan mangrove, sebagai sumber bahan industri dan obat-obatan, dan sebagai kawasan ekowisata dan konservasi.

Ekosistem mangrove di Kampung Nipah terdapat dua komponen yaitu komponen biotik dan abiotik. Komponen biotik terdiri dari jenis vegetasi dan beberapa fauna. Jenis vegetasi mangrove memiliki dua kategori, yaitu pertama mangrove sejati yang merupakan jenis mangrove yang tumbuh di tempat pasang surut air laut dengan substrat berlumpur asin yang memiliki kadar salinitas tinggi mulai dari zona terdepan (dekat dengan laut) sampai ke daratan dan yang kedua 
mangrove asosiasi yang merupakan jenis tumbuhan yang mampu beradaptasi dengan salinitas atau dikenal dengan mangrove pendamping.

Selain komunitas mangrove adapun fauna yang hidup di Kampung Nipah Desa Sei Nagalawan. Fauna yang terdapat pada ekosistem mangrove merupakan gabungan dari fauna ekosistem darat, peralihan, dan perairan. Fauna darat hidup terutama di hutan mangrove, sedangkan fauna peralihan dan akuatik hidup di akar mangrove dan kolom air. Beberapa fauna yang hidup di hutan mangrove Kampung Nipah Desa Sei Nagalawan ini merupakan tempat habitatnya, baik yang berimigrasi ataupun menetap, seperti kepiting bakau, ikan lundu, udang galah, ikan belanak, bangau putih dan ikan tembakul. Setiap fauna yang hidup di Kampung Nipah memiliki ciri khasnya tersendiri.

Temuan ini juga didukung oleh penelitian Prihadi (2018), dalam risetnya yang berjudul "Pengelolaan Kondisi Ekosistem Mangrove dan Daya Dukung Lingkungan Kawasan Wisata Bahari Mangrove di Karangsong Indramayu". Menurut Prihadi bahwa ada tiga jenis komunitas mangrove yang berada di Karangsong Indramayu yaitu Avicennia marina, Rhizophora stylosa, dan Rhizophora mucronata. Kawasan mangrove di Karangsong Indramayu ditemukan juga beberapa jenis fauna yaitu Kepiting Uca (Uca SP), Kepiting Bakau (Scyilla serata) yang berlimpah, sehingga bisa dimanfaatkan untuk masyarakat sekitar.

Komponen abiotik mempengaruhi pertumbuhan dan perkembangan hutan mangrove di Kampung Nipah yang meliputi suhu, cahaya, air, dan tanah. Suhu merupakan faktor yang sangat penting bagi distribusi atau penyebaran suatu makhluk hidup. Cahaya matahari merupakan sumber energi bagi seluruh makhluk hidup. Air merupakan komponen yang sangat penting bagi kehidupan makhluk hidup. Terakhir, tanah merupakan habitat sebagian besar makhluk hidup. Tumbuhan membutuhkan tanah sebagai sumber unsur hara maupun air. Komponen abiotik dapat mempengaruhi biotik, begitu pula dengan sebaliknya, sehingga hutan mangrove di Kampung Nipah dapat hidup sesuai dengan habitatnya.

Daerah Kampung Nipah Desa Sei Nagalawan, mempunyai zonasi hutan mangrove bergantung oleh kondisi tanah, salinitas, pasang surut, penggenangan, laju pengendapan, serta pengikisan. Secara umum, habitat vegetasi mangrove biasanya membentuk zonasi. Pola zonasi yang berbeda mulai dari daerah pinggir pantai sampai pedalaman merupakan kemampuan ekosistem mangrove yang sangat menarik dari hutan mangrove. Kawasan mangrove di Asia Pasifik tidak jauh berbeda dengan zonasi mangrove di Kampung Nipah Desa Sei Nagalawan. Zona frontal yang menggambarkan zona sangat dekat dengan laut didominasi oleh tipe pneumatophore yaitu Avicennia spp dan Sonneratia spp. Hasil yang sudah dijelaskan diatas ada 4 zonasi mangrove di Kampung Nipah yaitu : 1). Mangrove Payau ialah zona yang terletak di sepanjang sungai berair payau sampai nyaris tawar. Zona ini umumnya didominasi oleh komunitas Nypa ataupun Sonneratia. 2). Mangrove Terbuka merupakan zona yang terletak di bagian yang berhadapan dengan laut dan didominasi oleh Sonneratia danAvicennia. Kadang jenis Rhizophora juga terdapat pada zona ini. 3). Mangrove Tengah merupakan zona yang terletak dibelakang zona terbuka, umumnya didominasi oleh Rhizophora namun Bruguiera juga sering tumbuh pada zona ini. 4). Mangrove Daratan merupakan zona terdalam dibelakang zona mangrove sejati. Pada zona ini dapat ditemukan jenis-jenis mangrove asosiasi.

Hal ini didukung oleh Bengen di Fachrul (2007) dalam buku "Ekosistem dan Sumberdaya Pesisir dan Laut Serta Prinsip Pengelolaannya" menjelaskan bahwa daerah yang paling dekat dengan laut, dengan substrat yang agak berpasir, sering ditempati oleh jenis Avicennia sp. Di zona ini, umumnya berasosiasi dengan Sonneratia yang tumbuh terutama di lumpur dalam yang kaya bahan organik. Lebih lanjut di darat, hutan mangrove umumnya dijumpai oleh Rhizophora sp. Daerah ini juga ditemukan Bruguiera sp dan Xylocarpus sp. Sedangkan areal selanjutnya didominasi 
oleh Bruguiera sp. Zona transisi antara hutan mangrove dan hutan dataran rendah umumnya diserang oleh spesies palem dan beberapa lainnya.

\section{Pengelolaan Hutan Mangrove Berbasis Masyarakat}

Pengelolaan ekosistem hutan mangrove melalui perlibatan masyarakat menggambarkan suatu proses yang dinamis juga berkelanjutan yang menyatukan berbagai ilmu pengetahuan serta pengelolaan, kepentingan (pemerintah dan masyarakat), serta kepentingan sektoral dan masyarakat umum. Pengelolaan berbasis masyarakat disini merupakan penggunaan dari sumberdaya yang penting yaitu masyarakat juga harus menjadi pemeran pengelola sumberdaya tersebut. Pengelolaan sumberdaya tidak akan sukses tanpa melibatkan semua pihak yang mempunyai kepentingan (Rahim dan Baderan, 2017).

Suatu pembangunan berbasis masyarakat dapat tercipta, pada saat suatu kelompok bekerjasama, sebab mereka sadar tidak mampu mengerjakan suatu tugas secara individu dan tidak sanggup meraih tujuan secara individu baik akibat sifat dari tugas atau tujuan itu sendiri, maupun akibat keterbatasan sumber- sumber. Kebersamaan serta kesamaan dalam kepedulian dan perhatian, umumnya bisa dapat menyatukan masyarakat. Apabila kebersamaan itu melembaga, serta membangkitkan rasa saling percaya, rasa kesetiakawanan, terciptanya aturan-aturan main, maka inilah landasan dari terbentuknya basis masyarakat. Maka strategi yang tepat untuk dilaksanakan dalam menangani permasalahan yang mempengaruhi lingkungan pesisir dengan partisipasi aktif dan bentuk nyata dari masyarakat pesisir itu sendiri, dengan adanya partisipasi dari masyarakat menjadikan hal yang penting dalam upaya pengelolaan hutan mangrove berbasis masyarakat. Pelaksanaan program yang gagal mengikutsertakan masyarakat sejak awal program sehingga banyak program dan kegiatan pengelolaan yang kurang sukses.

Berdasarkan hasil penelitian yang telah diuraikan sebelumnya menunjukkan bahwa masyarakat yang ada di Kampung Nipah mengelola hutan mangrove dalam bentuk konservasi dilakukan dengan cara rehabilitasi dan responbility (tanggung jawab) serta mengoptimalisasikan fungsi dan manfaatnya yang sudah terjadi pada tahun 1980 dalam hal pertambakkan udang yang diseluruh kawasan pesisir timur Sumatera Utara. Berdasarkan teori dari Sofli (2003) yaitu pengelolaan ekosistem mangrove tersebut untuk mendapatkan pembuatan secara terus menerus dalam waktu yang relatif pendek demi menggapai sesuatu kondisi yang balance antara pertumbuhannya dengan hasil yang dipanen tiap tahun ataupun jangka waktu tertentu.

Kegiatan dalam pengelolaan hutan mangrove di Kampung Nipah meliputi tahap perencanaan, pelaksanaan, dan evaluasi. Hal ini didukung oleh penelitian Nurhalimah (2018) dengan judul "Partisipasi Masyarakat dalam Pengelolaan Hutan Mangrove Sicanang Kelurahan Sicanang Kecamatan Medan Belawan" dalam penelitiannya ada beberapa tingkatan partisipasi masyarakat pada tahap mengelola hutan mangrove. Pada tahap perencanaan ini diukur dari frekuensi pertemuan atau konsultasi sebelum keikutsertaan masyarakat dalam kegiatan penanaman mangrove, memanfaatkan mangrove dan antusiasme masyarakat dalam memberikan ide atau pendapat untuk meningkatkan kegiatan mangrove di Kampung Nipah. Pada tahap pelaksanaan frekuensi partisipasi masyarakat dalam kegiatan penanaman mangrove diawali oleh individu, kelompok dan LSM/pemerintah. Sedangkan tahapan evaluasi dapat dilihat dari kegiatan rapat pemeliharaan/menjaga kelestarian, supervisi dan evaluasi yang diadakan.

Pada hasil penelitian yang sudah diuraikan yaitu pada tahap perencanaan oleh masyarakat Kampung Nipah untuk mengelola hutan mangrove yang ada di Kampung Nipah tergolong kategori tinggi dengan proporsi $82,50 \%$, untuk kategori rendah 17,50\%. Masyarakat dalam kategori rendah merupakan masyarakat yang tidak pernah mengikuti atau hadir setiap kali diadakan pertemuan untuk merencanakan kegiatan dalam pengelolaan mangrove yang ada di 
Kampung Nipah. Masyarakat dalam kategori tinggi merupakan masyarakat yang sering mengikuti pertemuan dalam rangka perencanaan pengelolaan mangrove.

Pada tahap pelaksanaan oleh masyarakat Kampung Nipah tergolong tinggi dengan proporsi $72,50 \%$, untuk kategori rendah sebanyak 27,50\%. Masyarakat dalam kategori rendah merupakan masyarakat yang tidak pernah melakukan ataupun mengikuti kegiatan penanaman mangrove di Kampung Nipah dan masyarakat dengan kategori tinggi adalah masyakarat yang sering mengikuti kegiatan penanaman mangrove setiap kali diadakan kegiatan tersebut. Kampung Nipah Desa Sei Nagalawan selalu menyediakan bibit mangrove untuk kegiatan penanaman, mulai dari 100-500 bibit yang telah disediakan. Pada bulan Maret 2021 adanya salah satu ceremonial kegiatan penanaman yang dilakukan oleh pihak PTPN IV (PT Perkebunan Nusantara IV).

Pada tahap evaluasi oleh masyarakat Kampung Nipah tergolong tinggi 87,50\%, untuk kategori rendah sebanyak $12,50 \%$. Masyarakat dalam kategori rendah adalah masyarakat yang tidak pernah mengikuti kegiatan pemeliharaan/menjaga kelestarian mangrove, pengawasan dan evaluasi saat dilakukan kegiatan tersebut. Masyarakat yang termasuk dalam kategori tinggi merupakan masyarakat yang sering dan aktif mengikuti kegiatan tersebut.

Sebagai sesuatu ekosistem serta sumberdaya alam, pemanfaatan mangrove ditunjukan buat kesejahteraan umat. Supaya pemanfaatannya bisa berkepanjangan, hingga ekosistem mangrove butuh dikelola serta dilindungi keberadaannya. Ada dua konsep utama dalam pengelolaan mangrove. Awalnya, perlindungan mangrove merupakan upaya melindungi mangrove menjadi kawasan mangrove lindung. Kedua, restorasi mangrove merupakan kegiatan reboisasi yang dilakukan di lahan yang dulunya merupakan hutan mangrove. Restorasi bertujuan tidak hanya mengembalikan nilai estetika, tetapi juga mengembalikan manfaat ekologis kawasan mangrove yang telah ditebang dan dialihkan untuk kegiatan lain (Patang, 2012).

\section{Pemanfaatan Hutan Mangrove}

Pemanfaatan hutan mangrove di Kampung Nipah Desa Sei Nagalawan memberikan banyak manfaat langsung terutama dari segi ekonomi. Dari 40 KK masyarakat memperoleh pendapatan dari hasil hutan mangrove itu sendiri. Masyarakat memanfaatkannya dengan cara mengolah mangrove dalam bentuk makanan, minuman, maupun bahan industri rumah tangga seperti arang, kayu bakar, zat pewarna, perikanan dan lain-lain. Hal ini didukung dengan penelitian Restu (2017) dengan judul penelitian "Analisis Manfaat Hutan Mangrove di Desa Tanjung Rejo Kecamatan Percut Sei Tuan Kabupaten Deli Serdang” bahwa hutan mangrove memiliki nilai manfaat langsung maupun tidak langsung. Manfaat langsung yang dirasakan oleh Desa Tanjung Rejo adalah tambak dan pemancingan, kepiting, udang, ikan, kerang, ekowisata, pewarnaan batik dan kayu bakar, sedangkan manfaat tidak langsung yang dirasakan oleh warga desa Tanjung Rejo adalah hutan bakau sebagai ketahanan intrusi pantai dan air laut.

Bagian mangrove yang dominan dimanfaatkan masyarakat Kampung Nipah yaitu bagian daun, buah, dan batangnya. Setiap masyarakat berbeda-beda cara memanfaatkan bagian-bagian mangrove. Bagian daun dapat diolah menjadi kerupuk dan teh. Bagian buah dapat diolah menjadi sirup, keripik dan dodol. Sedangkan bagian batangnya dapat diolah menjadi bahan bakar kebutuhan rumah tangga seperti arang, kayu bakar, zat pewarna dan lain-lain. Mangrove yang telah digunakan sebagai bahan makanan ataupun bahan industri itu tidak merusak mangrove. Alasannya, karena mangrove yang digunakan bisa tumbuh kembali dengan sendirinya, dan yang diambil dari mangrove tersebut bagian pentingnya saja bukan secara keseluruhan. Seperti hal nya dengan daun jeruju yang diolah menjadi kerupuk. Daunnya saja yang diambil dan diolah menjadi makanan. Dalam hal ini masyarakat memiliki pendapatan sekaligus melestarikan dari hutan mangrove yang ada di Kampung Nipah. Mangrove tidak boleh ditebang sembarangan karena akan dikenakan sanksi dari pihak yang berkewajiban dan ketika mangrove sudah mati otomatis 
akan ditebang atau dibiarkan, dan hal itu tidak merusak fungsi mangrove yang lain sekaligus pemanfaatannya.

Olahan mangrove tersebut dipasarkan di Pantai Mangrove Kampung Nipah tempat wisatawan berkunjung. Pada awalnya dipasarkan di pasar bengkel Perbaungan, namun hasil yang didapatkan tidak memenuhi kebutuhan. Sehingga, masyarakat Kampung Nipah hanya memasarkan di tempat wisata Pantai Mangrove saja dan itu lebih banyak menguntungkan daripada dipasarkan di pasar bengkel Perbaungan. Akan tetapi, jika para wisatawan ingin membeli secara paketan itu seharga Rp. 300.000,- dengan satu jenisnya atau per/kg nya itu dijual seharga Rp. 80.000,- dan jika membeli satu bungkus dijual dengan harga Rp. 8.000,-. Penghasilan yang didapatkan di tempat wisata lebih menguntungkan dan jika membelinya akan ikut melestarikan hutan mangrove di Kampung Nipah.

Masyarakat di Kampung Nipah Desa Sei Nagalawan sebanyak 40 KK yang menjadi informan secara menyeluruh mengetahui pemanfaatan mangrove secara tidak langsung (fisik dan biologi). Seperti mencegah abrasi pantai yang merupakan suatu pengikisan tanah pada pesisir pantai yang diakibatkan oleh gelombang air laut dan arus laut. Sebagai penahan intrusi laut dikarenakan perakaran mangrove dapat mengendapkan lumpur yang telah tercampur dengan air asin, dengan hal ini hutan mangrove berperan penting untuk mengurangi intensitas air laut yang menyebar sampai ke daratan. Sebagai penghasil oksigen, melindungi pantai dari badai dan taufan dan penyedia bahan makanan serta pemijahan bagi biota-biota yang hidup di dalamnya. Hal ini didukung oleh Fitriah (2013) yang menyatakan bahwa fungsi serta manfaat dari mangrove sangat banyak di ketahui, seperti tempat pemijahan ikan, sebagai pencegahan abrasi laut, pelindung dari tiupan angin, dan masih banyak lainnya.

Pada dasarnya seperti yang sudah diuraikan di hasil penelitian, bahwa terjadinya abrasi pantai di Pantai Mangrove dikarenakan kurangnya lahan untuk kegiatan penanaman mangrove, sehingga yang tidak terduga bisa terjadi abrasi pantai di Pantai Mangrove tersebut. Akan tetapi, ketua pengelola beserta rekan-rekannya di Kampung Nipah akan berusaha menangani hal ini dengan berbagai cara apapun, agar masyarakat tidak terkena dampak akibat untuk kedepannya.

Sedangkan manfaat pilihan, masyarakat di Kampung Nipah membuat tempat ekowisata. Ekowisata merupakan salah satu kegiatan pariwisata ramah lingkungan, yang dapat melihat, mempelajari, flora dan fauna, menghargai alam dan sosial budaya etnik masyarakat setempat. Ekowisata yang terdapat di Kampung Nipah yaitu ekowisata di Pantai Mangrove, dengan bertujuan untuk mengubah sikap dan perilaku masyarakat melalui unsur edukatif sehingga menimbulkan kepedulian, tanggung jawab dan komitmen dalam menjaga lingkungan dan budaya. Adapun prinsip dari ekowisata mangrove di Kampung Nipah Desa Sei Nagalawan ini adalah pengembangan ekowisata harus mampu memberikan pengalaman yang asli dan memuaskan kepada wisatawan serta menjamin adanya bisnis ekowisata yang memuaskan di Pantai Mangrove Kampung Nipah Desa Sei Nagalawan dapat berkelanjutan. Hal ini didukung oleh penelitian Maulina (2011) bahwa ekowisata menggambarkan salah satu alternatif program yang bisa diterapkan buat peningkatan kesejahteraan warga setempat selaku upaya yang bisa dicoba untuk mengestimasi terjadinya kerusakan ekosistem mangrove. Di sisi lain, fasilitas serta prasarana penunjang pengelolaan dan pelayanan wisatawan yang diperlukan buat pengembangan ekowisata wajib mencukupi buat menarik atensi wisatawan ataupun pelancong. 


\section{KESIMPULAN}

Berdasarkan hasil penelitian yang dilakukan di Kampung Nipah Desa Sei Nagalawan dapat disimpulkan sebagai berikut :

Ekosistem hutan mangrove di Kampung Nipah Desa Sei Nagalawan terdiri dari dua komponen, komponen biotik dan abiotik. Komponen biotik terdiri dari jenis vegetasi, jenis fauna dan zonasi mangrove. Komponen abiotik terdiri dari suhu, cahaya, air dan tanah. Kedua komponen ini saling mempengaruhi di Kampung Nipah.

Masyarakat di Kampung Nipah Desa Sei Nagalawan mengelola hutan mangrove dalam bentuk konservasi yang dilakukan dengan cara rehabilitasi dan responbility (tanggung jawab). Kegiatan dalam pengelolaan hutan mangrove meliputi tahap perencanaan, pelaksanaan, dan evaluasi.

Masyarakat di Kampung Nipah Desa Sei Nagalawan memanfaatkan hutan mangrove dengan sangat baik, dari manfaat langsung, manfaat tidak langsung maupun manfaat pilihan. Manfaat langsung, masyarakat mengolah mangrove sebagai sumber mata pencaharian, seperti perikanan, produksi berbagai hasil hutan (kayu, arang, dan makanan) dan sumber bahan bangunan. Sedangkan manfaat tidak langsung masyarakat mengetahui bahwa keberadaan mangrove melindungi pantai dari abrasi dan intrusi air laut, penghasil oksigen, mencegah gelombang air laut, mencari makan dan daerah pemijahan dari berbagai biota laut. Terakhir manfaat pilhan, masyarakat membuat ekowisata di Pantai Mangrove.

\section{REFERENSI}

Ambar, Teguh Sulistiyani. 2004. Kemitraan dan Model-Model Pemberdayaan. Yogyakarta: Gava Media.

Anwar, C., \& Gunawan, H. (2006). Peranan ekologis dan sosial ekonomis hutan mangrove dalam mendukung pembangunan wilayah pesisir. Makalah Utama pada Ekspose Hasil-hasil Penelitian: Konservasi dan Rehabilitasi Sumberdaya Hutan. Padang, 20, 23-34.

Bengen, D G. 2002. Sinopsis Ekosistem dan Sumberdaya Pesisir dan Laut Serta Prinsip Pengelolaannya. Cetakan Kedua. Bogor: Pusat Kajian Sumber Daya Pesisir dan Lautan, Institut Pertanian Bogor.

Binawati,Diah Karunia.dkk.2015. Konservasi Hutan Mangrove Untuk Meningkatkan Perekonomian Masyarakat Kawasan Pesisir Di Pulau Mengare Kec. Bungah Kab. Gresik Propinsi Jawa Timur. Prosiding Seminar Nasional "Research Month". Hal. 311-319. diakses Minggu 08 November 2020.

Djamaluddin, Rignolda. 2018. Mangrove Biologi, Ekologi, Rehabilitasi, dan Konservasi. Manado : Unsrat Press.

Halidah, H., Saprudin, S., \& Anwar, C. (2008). Potensi dan ragam pemanfaatan mangrove untuk pengelolaannya di Sinjai Timur, Sulawesi Selatan. Jurnal Penelitian Hutan dan Konservasi Alam, 5(1), 67-78.

Hilmanto, R. 2012. Buku Penuntun Praktikum Manajemen Hutan Mangrove. Jurusan Kehutanan Universitas Lampung. Bandar Lampung.

Karminarsih, E. (2007). Pemanfaatan ekosistem mangrove bagi minimasi dampak bencana di wilayah pesisir. Jurnal Manajemen Hutan Tropika, 13(3), 182-187. 
Kementerian Lingkungan Hidup dan kehutanan. 2017. Pada link (http://ppid.menlhk.go.id/siaranpers/browse/561)

Kementerian Kelautan dan Perikanan, 2019. Pada link (https://kkp.go.id/artikel/12993-lautmasa-depan-bangsa-mari-jaga-bersama)

Kustanti, A., \& Kusmana, C. (2011). Manajemen hutan mangrove. IPB Press.

Macintosh, D. J. dan E. C, Ashton. (2003) 'Report on the Central and South America Regional Workshop on the Sustainable Management of Mangrove Forest Ecosystems Edited by'.

Media Sumut. 6 September 2020. Kondisi Hutan Mangrove di Sumatera Utara. Diakses pada 25 November 2020.

Nurhalimah, 2018. Partisipasi Masyarakat dalam Pengelolaan Hutan Mangrove Sicanang Kelurahan Sicanang Kecamatan Medan Belawan. Diakses tanggal 20 April 2021. Pada link (http://repositori.usu.ac.id/hasil-skripsi-manajemen-kehutanan)

Ontorael, R., Wantasen, A. S., \& Rondonuwu, A. B. (2012). Kondisi ekologi dan pemanfaatan sumberdaya mangrove di Desa Tarohan Selatan Kecamatan Beo Selatan Kabupaten Kepulauan Talaud. Jurnal Ilmiah PLATAX, 1(1), 07-11.

Patang. (2012). Analisis Strategi Pengelolaan Hutan Mangrove (Kasus di Desa Tongke-Tongke Kabupaten Sinjai). Jurnal Agrisistem, 8(2), 100-109.

Peraturan Presiden Nomor 73 Tahun 2012 tentang Strategi Nasional Pengelolaan Ekosistem Mangrove

Prihadi, D. J., Riyantini, I. R., \& Ismail, M. R. (2018). Pengelolaan kondisi ekosistem mangrove dan daya dukung lingkungan kawasan wisata bahari mangrove di Karangsong Indramayu. Jurnal Kelautan Nasional, 13(1), 53-64.

Rahim,Sukirman.dkk. 2017. Hutan Mangrove Dan Pemanfaaanya. Yogyakarta: DEEPUBLISH.

Romimohtarto, Kasijan dan Sri, Juwana. 2001. Biologi Laut: Ilmu Pengetahuan tentang Biota Laut.Puslitbang Oseanologi LIPI. Jakarta.

Samosir, D. D., \& Restu, R. Analisis Manfaat Hutan Mangrove di Desa Tanjung Rejo Kecamatan Percut Sei Tuan Kabupaten Deli Serdang Sumatera Utara. Tunas Geografi, 6(1), 1-15.

Saputro, A., Nyompa, S., \& Arfan, A. (2019). Analisis Pemanfaatan Hutan Mangrove dan Kontribusinya Terhadap Pendapatan Rumah Tangga Masyarakat di Pulau Tanakeke Kabupaten Takalar. LaGeografia, 18(1), 70-81.

Saragi, S. M., \& Desrita, D. (2018). Ekosistem mangrove sebagai habitat kepiting bakau (Scylla Serrata) di Kampung Nipah Desa Sei Nagalawan Kecamatan Perbaungan Serdang Bedagai Provinsi Sumatera Utara. DEPIK Jurnal Ilmu-Ilmu Perairan, Pesisir dan Perikanan, 7(1), 84-90.

Sekartjakrarini. (2009). Kriteria Dan Indikator Ekowisata Indonesia. Bogor: IdeA.

Simamora, N. 2018. Partisipasi Masyarakat dalam Pengelolaan Hutan Mangrove Sicanang Kelurahan Sicanang Kecamatan Medan Belawan (internet). (Diunduh pada 14 April 2021). Tersedia pada link:

http://repositori.usu.ac.id/bitstream/handle/123456789/5585/141201135.pdf?sequence=5\&isA llowed=y

Sofli WA. 2003. Kajian Partisipasi Masyarakat dalam Pengelolaan Hutan Mangrove (internet). (Diunduh pada 22 Januari 2021). Tersedia pada: http://repository.ipb.ac.id/bitstream/handle/123456789/8014/2003wrs.Pdf? sequence $=4 \&$ is Allowed $=\mathrm{y}$

Wahyuni, S. (2015). Strategi Pengembangan Ekowisata Mangrove Wonorejo, Kecamatan Rungkut Surabaya. Management Of Aquatic Resoures, 66-68.

Tambunan, Iqbal. 2018. Pengaruh Lingkungan Tempat Tinggal Terhadap Pengetahuan Siswa Tentang Ekosistem Mangrove Di Kabupaten Deli Serdang. Jurnal Biolokus. Vol 1 (1). 